\title{
The dangers of hanging baskets: 'Regulatory myths' and media representations of health and safety regulation
}

Article

Accepted Version

Almond, P. (2009) The dangers of hanging baskets:

'Regulatory myths' and media representations of health and safety regulation. Journal of Law and Society, 36 (3). pp. 352375. ISSN 0263-323X doi: https://doi.org/10.1111/j.14676478.2009.00471.x Available at https://centaur.reading.ac.uk/6613/

It is advisable to refer to the publisher's version if you intend to cite from the work. See Guidance on citing.

To link to this article DOI: http://dx.doi.org/10.1111/j.1467-6478.2009.00471.x

Publisher: Wiley-Blackwell

All outputs in CentAUR are protected by Intellectual Property Rights law, including copyright law. Copyright and IPR is retained by the creators or other copyright holders. Terms and conditions for use of this material are defined in the End User Agreement. 


\section{CentAUR}

Central Archive at the University of Reading

Reading's research outputs online 


\section{'The Dangers of Hanging Baskets: 'Regulatory Myths' and Media}

\section{Representations of Health and Safety Regulation'}

\section{Introduction}

The process of exercising regulatory controls over the conduct of individuals and corporate bodies is an explicitly social one, in that it involves the communication of a wide range of messages to a number of different audiences. As well as performing a directive function by requiring people to behave in a certain way in pursuit of desired outcomes, regulatory legal controls also perform symbolic and expressive functions, in that they communicate a moral message about the desirability and acceptability of certain forms of conduct. In particular, regulatory enforcement activities provide a forum for the communication of important messages about social risks, the culpability of those who create these risks, and the status of the law and regulators governing them. ${ }^{1}$ Enforcement activity allows regulatory agencies to demonstrate their organisational legitimacy by establishing the moral rightness and procedural fairness of their actions. ${ }^{2}$ Yet this process of 'legitimation' is double-edged; while successful regulatory enforcement action can establish organisational legitimacy, ill-judged enforcement activity can also undermine it.

This paper will investigate one area in which the legitimacy of a specific regulatory agency, the UK Health and Safety Executive (HSE), has been challenged by negative public evaluations of its enforcement activity. ${ }^{3}$ While previous research has examined the ways in

\footnotetext{
${ }^{1}$ K. Hawkins, Law as Last Resort: Prosecution Decision-Making in a Regulatory Agency (2002).

2 P. Almond, 'Regulation Crisis: Evaluating the Potential Legitimising Effects of 'Corporate Manslaughter' Cases' (2007) 29 Law and Policy 285; F. Haines and D. Gurney, 'The Shadows of the Law: Approaches to Regulation and the Problem of Regulatory Conflict' (2003) 25 Law and Policy 353.

${ }^{3}$ The increasing public profile of this issue, and of these negative public evaluations, is evidenced in the broadcast on UK national television of two documentaries on health and safety in 2008 and early 2009; 'Cutting Edge: The Fun Police', Channel 4, 04/12/2009, and 'Panorama: May Contain Nuts', BBC1, 20/04/2009.
} 
which organisational legitimacy can be affected by large-scale and serious cases, the potential for delegitimatory impact is not restricted to these 'big' cases. In particular, it is important to look at the ways in which 'frivolous' minor cases, such as those involving tales of heavyhanded and disproportionate enforcement, the petty implementation of regulations, and the adoption of unnecessarily bureaucratic approaches to issues of health and safety, can impact on perceptions of regulators and the law. Such cases are a familiar media feature and are afforded significant coverage; this has prompted official attempts by regulators like HSE to try and mitigate the negative effects of these stories.

This paper will argue that these stories constitute something more significant than just amusing media features and, as such, merit serious analysis. They can be characterised as 'regulatory myths', in that their popularity transcends their factual validity, and their meanings derive from the wider political significance that they possess. Regulatory myths provide a forum for the communication of moral messages about the law, and for reassessment of the legitimacy of regulators and the system of regulatory law that underpins them. Crucially, while these stories involve challenges to the 'moral legitimacy' of the regulator involved, they also present challenges to the 'procedural validity' of the agency as well, ${ }^{4}$ thereby calling into question not only the substance of the regulatory outcomes in question, but also the right of the regulator to impose legal controls. As such, these stories merit serious analysis as potential catalysts of regulatory delegitimation.

\section{"Health and safety gone mad": The problem of 'frivolous' regulatory cases}

It is relatively rare for news stories concerning regulatory issues and enforcement activities, particularly within the context of health and safety regulation, to garner significant media

\footnotetext{
${ }^{4}$ D. Beetham, The Legitimacy of Power (1991).
} 
attention (Ericson 1991; Levi 2006; Wells 2001), ${ }^{5}$ with two primary exceptions. The first relates to coverage of major cases, often those involving large-scale public disasters such as the Southall (1995), Ladbroke Grove (1999), Hatfield (2000), and Potters Bar (2002) rail crashes, which are capable of prompting high levels of public concern ${ }^{6}$ and initiating subsequent legal change. ${ }^{7}$ The significance of these cases is a product of their perceived seriousness and social function as indicators of wider risks and sources of insecurity. ${ }^{8}$ As such, serious breaches of health and safety law, such as work-related fatality cases, possess a social significance far in excess of that attaching to most health and safety-related regulation.

The second exception relates to a particular type of news story concerning regulatory activity, which may be characterised as diametrically opposite in nature to these 'big' cases. This second category of cases do not typically involve high levels of seriousness, either in terms of harm or wrongfulness, and unlike 'moral panics' over crime issues, ${ }^{9}$ do not relate to issues of aggregated risk or to dangers that affect the wider community. Instead, the stories in this second category involve reports of inappropriate regulatory activity, and focus their negative attention on the regulator involved rather than any offender. They outline situations where regulators are interpreted as having been overly zealous or heavy-handed in applying or enforcing legal requirements. In addition, the stories usually involve conflict between the 'ordinary man' and a powerful, impersonal regulatory bureaucracy, thereby establishing the essential 'otherness' of regulators and aligning the sympathies of the audience with the

\footnotetext{
${ }^{5}$ R. Ericson, 'Mass Media, Crime, Law and Justice: An Institutional Approach' (1991) 31 British Journal of Criminology 219; M. Levi, 'The Media Construction of Financial White-Collar Crimes' (2006) 46 British Journal of Criminology 1037; C. Wells, Corporations and Criminal Responsibility ( $2^{\text {nd }}$ ed.) (2001).

${ }^{6}$ P. Almond, 'Public Perceptions of Work-Related Fatality Cases: Reaching the Outer Limits of 'Populist Punitiveness' (2008) 48 British Journal of Criminology 448.

${ }^{7}$ F. Haines, 'Innocent Deaths and Regulatory Failure: A Case Study of Change in the Absence of Punishment' (1999) 27 International Journal of the Sociology of Law 23.

${ }^{8}$ Almond, op. cit., n.6; B. Hutter and S. Lloyd-Bostock, 'The Power of Accidents: The Social and Psychological Impact of Accidents and the Enforcement of Safety Regulations' (1990) 30 British Journal of Criminology 409; Wells, op. cit., n. 5.

${ }^{9}$ S. Cohen, Folk Devils and Moral Panics: The Creation of the Mods and Rockers (1972); E. Goode and N. BenYahuda, Moral Panics: The Social Construction of Deviance (1994).
} 
'ordinary man'. ${ }^{10}$ For the purposes of this paper, these cases will be referred to as 'frivolous', so as to reflect their lack of objective seriousness and derisive tone.

One of the most widely-reported frivolous cases of recent times has been a recurring story concerning the intervention of health and safety professionals to 'ban' floral display hanging baskets from town centres in England, on the basis that they pose a health and safety risk to members of the public as they could fall and injure passers-by. ${ }^{11}$ Versions of this story have been reported that involve the removal of council displays on lamp-posts in Norfolk, ${ }^{12}$ Suffolk, ${ }^{13}$ Somerset, ${ }^{14}$ Scotland, ${ }^{15}$ and so on. These stories conform to the confrontational model outlined above, describing the 'outraged' and 'stunned' reactions of members of the public, and featuring references to the 'over-officious' regulators who impose these controls. The stories critically characterise the regulatory interventions as 'kill-joy' measures and 'political correctness gone mad', and are explicitly critical in their assessments of the regulator or safety official involved.

There are other prominent examples of frivolous cases to be found in the media, including the prevention by teachers in Cumbria of schoolchildren from playing the traditional child's game

\footnotetext{
${ }^{10}$ This constitutes an interesting inversion of the mechanics through which conceptions of the criminal 'other' are constructed as part of law and order politics according to D. Garland, The Culture of Control: Crime and Social Order in Contemporary Society (2001) p. 134-6, p. 184-6, and others. Accounts of the contemporary culture of crime control stress the way in which offenders are constructed as being different from, and in opposition with, the law-abiding majority and the forces of law and order, because they are viewed as intrinsically criminalistic, dangerous, irrational, and unintelligible. In the situation outlined here, however, it is the law enforcement agency which is represented as 'other', and as irrational and unintelligible. The 'personalisation' of crime policy cuts both ways, and can serve to distance the bureaucracy of law enforcement from the public.

${ }^{11}$ K. Williams, 'Politics, the Media and Refining the Notion of Fault: Section 1 of the Compensation Act 2006' (2006) 4 Journal of Personal Injury Law 347, p. 349.

12 “'Officious' council's hanging basket ban', Watton and Swaffham Times, 19/09/07

(http://www.wattonandswaffhamtimes.co.uk/content/wstimes/news/story.aspx?brand=WSOnline\&category=new s\&tBrand=WSOnline\&tCategory=news\&itemid=NOED19\%20Sep\%202007\%2017\%3A32\%3A17\%3A517); Health and safety killjoys order award-winning village to take down its hanging baskets', Daily Mail, 10/01/08 (http://www.dailymail.co.uk/pages/live/articles/news/news.html?in_article id=507355\&in_page id=1770).

13 'Town bans hanging baskets', BBC News, 10/02/04; http://news.bbc.co.uk/1/hi/england/suffolk/3475431.stm.

14 'Village pub's blooms are banned as a safety hazard', The Times, 11/07/05 p25.

15 'Baskets a bloomin' nuisance; council chief fears accident', Daily Record, 23/10/06 p19.
} 
of conkers without safety goggles to prevent eye injuries, ${ }^{16}$ and the banning of traditional pancake-tossing races in Yorkshire due to the impact of health and safety risk assessments and restrictions, ${ }^{17}$ both of which have the same basic features as the 'hanging baskets' stories. Like the 'hanging baskets' cases, the 'conkers' case has achieved a degree of popular currency that transcends the original boundaries of the story itself. It is now commonly cited in media commentary on health and safety issues as an example of regulatory excess, ${ }^{18}$ and the basic thread of the story has entered into the common consciousness; a Google search for the search terms 'conker', 'goggles', and 'ban' together generates 979 matches with websites from the United Kingdom. The secondary references to this story do not generally explain the full circumstances, usually implying that the requirement of goggles had been externally imposed by a regulator rather than, as was the case, voluntarily adopted by the teacher involved as a publicity stunt. ${ }^{19}$ Similar secondary references to the 'hanging basket' cases are numerous, and also omit essential details of the cases, such as the fact that no baskets in the featured cases were ever actually removed following risk assessments; both of these influential stories are essentially false. ${ }^{20}$

The media play a vitally important role in promulgating and disseminating stories of this type, as it is through a process of secondary reproduction and repetition that frivolous cases become well-known and acquire significance, a process which gives the story a life almost

\footnotetext{
16 'Pupils told to wear goggles for conkers', Daily Telegraph, 04/10/2004 p1; 'Safer conkers', The Times, $04 / 10 / 2004$ p 26 .

17 'Health and safety rules trip up pancake race', Daily Telegraph, 07/02/2008 p5; 'Red tape kills city's pancake race dating from pre-medieval times', The Guardian, 05/02/2008 p4.

18 'I'm warning you for your own good, No 10 is on the case', The Sunday Times News Review, 20/01/2008 p2; 'Who Will Regulate the Regulators?', The Times, 29/10/2007 p16; 'Taste of country life denied to one in five children', Daily Telegraph, 09/04/2008 p9; 'Schools refuse to be conkered', The Guardian, 12/10/2004 (http://education.guardian.co.uk/schools/story/0,5500,1325508,00.html).

${ }^{19}$ In an ironic postscript to the 'conker' story, a team representing the Institution of Occupational Safety and Health (IOSH) entered and sponsored the World Conker Championships in Northamptonshire in 2007, in an effort to mend some of the damage that the story had inflicted on their profession; 'Safety officials who came, saw, and conkered', The Times, 15/10/2007 (http://www.timesonline.co.uk/tol/news/uk/article2658184.ece). ${ }^{20}$ Williams, op. cit., n.11, p. 349.
} 
independent from the circumstances of the original case. The stories may not involve any formal regulatory activity and are relatively non-specific, making it hard to establish any 'truth' that may underpin them, but this non-specificity is also the reason that they are so influential, as it allows them to function as shorthand signals of generalised regulatory inappropriateness. The media have an interest in reporting these studies because of their surface entertainment value and links to wider societal concerns, ${ }^{21}$ but they are not merely items of 'info-tainment'. Rather, they reflect wider political agendas and vested interests relating to issues of business responsibility and accountability, feeding into media-perpetuated social discourses about the desirability of limiting the 'drain on the economy' constituted by systems of regulation and legal control. ${ }^{22}$

In particular, there is a direct link between the frivolous regulatory cases discussed here and the broader phenomenon of the 'compensation culture'; the perception that society has become increasingly litigious and blame-focused, that the numbers of personal injury tort cases and the amount of compensation awarded have increased markedly, and that the result has been a diminution of notions of personal responsibility and self-reliance and an increase in risk-aversion and fear of being sued. ${ }^{23}$ The research literature on this topic has established that the perceived increase in litigation is heavily overstated, and that much of this concern has been prompted by media coverage which is simplistic, partisan, and reflective of particular ideologies and interest group agendas. Haltom and McCann documented the American media's role in promulgating a 'tort reform' agenda through the dissemination of

\footnotetext{
${ }^{21}$ A. Morris, 'Spiralling or Stabilising? The Compensation Culture and Our Propensity to Claim Damages for Personal Injury' (2007) 70 Modern Law Review 349, p. 364; the links between these stories and issues of concern are discussed at length below.

${ }^{22}$ W. Haltom and M. McCann, Distorting the Law: Politics, Media and the Litigation Crisis (2004) 149; Morris, id., p365.

${ }^{23}$ Haltom and McCann, id.; Morris, op. cit., n. 21; Williams, op. cit., n. 11; K. Williams, 'State of Fear: Britain's

'Compensation Culture' Reviewed' (2007) 25 Legal Studies 500.
} 
'tort tales', myth cases featuring undeserving plaintiffs and outrageous damages awards. ${ }^{24}$ This study showed how the production of these stories reflects both an instrumental effort on the part of business lobby campaigners to use tort tales to campaign for reform of the law to restrict corporate exposure to civil liability, and also the institutional role of media outlets in disseminating tort tales as a form of 'common-sense' knowledge production. As dramatic, personalised, stand-alone stories that represent a specific issue as reflective of the normality of modern life, frivolous cases, like tort tales, fit perfectly with the institutional requirements of the news production process, and so they become seen as credible because so widely reproduced.

Like tort tales, frivolous cases reflect wider concerns about the existence of an increasingly individualistic society, and tie in with other examples of public backlash against the "nanny state', 'political correctness', and 'red tape'. To this end, the origins of frivolous cases lie in the general context of the compensation culture, and reflect many of the same concerns, emerging in parallel (and often in tandem) with tort tales. Indeed, many frivolous case reports refer directly to the 'compensation culture' and the idea that over-zealous health and safety provision is motivated by a desire to avoid being sued. The political aim or purpose that underpins their emergence relates to a desire to discredit regulators and systems of law that make business interests accountable to those affected by their actions, and to influence political developments in this area. ${ }^{25}$ News narratives then form the basis for the further dissemination of tort tales and frivolous cases into the wider social consciousness because the interesting and easily understandable stories produced can easily be packaged for wider consumption. In this way, the media both feed off the stories that interest groups promote, and also produce stories which bolster the claims of those interest groups.

\footnotetext{
${ }^{24}$ Haltom and McCann, id., p. 154-159.

${ }^{25}$ See the introduction of the Compensation Act 2006; Williams, op. cit., n. 11, p. 350.
} 
The widespread coverage and prominence within the public consciousness of frivolous cases has prompted a range of responses from the regulatory bodies seen to be associated with them. Health and safety law within the UK constitutes an increasingly diverse body of regulatory rules, much of which stems from the European Union (which itself is commonly referenced in 'frivolous cases'). In addition, health and safety requirements are constructed and enforced by a plethora of organisational actors, including local government authorities, commercial insurers, the Police, and other government departments such as the Department for Transport. Together, these bodies constitute a health and safety system which is little understood and regarded rather ambivalently by the general public, ${ }^{26}$ and it is HSE which constitutes the most recognisable and visible manifestation of this system. As such, the analysis that follows will engage mainly with the effects that 'frivolous cases' have on perceptions of this agency in particular.

HSE has been prompted to respond to the spread of stories about 'frivolous cases' by launching a 'Sensible Risk Management' policy in 2005 to try and counteract their negative impacts. In a speech at the House of Lords, the then Chair of the Health and Safety Commission (as was), Sir Bill Callaghan, stated that these cases:

“...matter to HSE not just because [they] trivialise our work... all of this stands to damage the name of health and safety, making it harder for all [stakeholders] to focus attention on the significant risks that result in serious harm and even death...we will

\footnotetext{
${ }^{26}$ J. Walls, N. Pidgeon, A. Weyman and T. Horlick-Jones, 'Critical Trust: Understanding Lay Perceptions of Health and Safety Risk Regulation' (2004) 6 Health, Risk, and Society 133.
} 
not be taken seriously or listened to if employers...think that we are not just banning conkers but banning ladders or preventing farmers from driving tractors. "27

As such, HSE has undertaken a range of activities, including the publication of a 'myth of the month' feature on their website, the publication of HSE's 'Principles of Sensible Risk Management', which aim to facilitate the adoption of health and safety policies that "balance benefits and risks, with a focus on reducing real risks", and that do not "scare people by exaggerating or publicising trivial risks", ${ }^{28}$ and a marked stepping-up of the agency's efforts to engage with media outlets in order to rebut these 'myths'. ${ }^{29}$ This constitutes a restatement of the specific commitment to 'consistent and proportionate' enforcement activity contained within HSE's Enforcement Policy Statement. ${ }^{30}$

These corrective measures aim to undo the damage to HSE's profile inflicted by frivolous cases, on the basis that a wider perception of HSE as "excessively risk-averse and nannying" may detrimentally affect the agency's other regulatory activities. ${ }^{31}$ The enforcement approach taken by HSE has been identified as primarily consensual, conciliatory, and self-regulatory in nature wherein enforcement action is employed sparingly, and prosecution occurs as a 'last resort'. ${ }^{32}$ This regulatory approach places the primary responsibility for achieving

\footnotetext{
${ }^{27}$ B. Callaghan, Introductory Address: Health and Safety-Sensible Management or Bureaucratic Straitjacket? (2005) (http://www.hse.gov.uk/risk/billcallaghan2.pdf), 13/7/2005; HSE, Sensible Risk Management (2006) HSE Board Paper HSE/06/46, 13/04/2006.

${ }^{28}$ These principles, along with the 'myth of the month', are not formally published by HSE but can be found on the HSE website at http://www.hse.gov.uk/risk/principles.htm. These attempts to restate the significance of health and safety regulation are mirrored in the dicta of Lord Hope of Craighead in R v. Chargot \& Ors. [2009] 1 WLR 1 at para. 27: “... when the legislation refers to risks it is not contemplating risks that are trivial or fanciful. It is not its purpose to impose burdens on employers that are wholly unreasonable."

${ }^{29}$ For instance, Letters to the Editor, The Times, 05/10/2004; 'The HSE accepts that risk is part of life', The Guardian, 30/05/2007 (http://www.guardian.co.uk/commentisfree/2006/nov/28/comment.politics2); 'Safety first, but keep it sane', The Times, 31/07/2007 p5; 'Get a life and take sensible risks, says safety chief', Daily Telegraph, 23/08/2006 (http://www.telegraph.co.uk/news/main.jhtml?xml=/news/2006/08/23/nrisk23.xml).

${ }^{30}$ HSE, Enforcement Policy Statement (2008).

${ }^{31}$ HSE, op. cit., n. 27.

${ }^{32}$ B. Hutter, Compliance: Regulation and Environment (1997); Robens, Safety and Health at Work: Report of the Committee 1970-72 ('The Robens Report') (1972); Wells, op. cit., n. 5; Hawkins, op. cit., n. 1.
} 
compliance with health and safety requirements upon the regulated company themselves, ${ }^{33} \mathrm{a}$ trend given new impetus by recent governmental restatements of deregulatory intent. ${ }^{34}$ HSE's primary regulatory responsibilities are to provide information and guidance to the regulated, and to investigate incidents when things go wrong. This reflects a desire to 'responsibilise' companies and a belief in the value of cooperative regulation, ${ }^{35}$ and requires commitment to a broadly consensual relationship between regulator and regulated from both parties; this underlines the potential for the regulatory process to be undermined by events that damage the public profile of the regulator.

One of the most detailed accounts of HSE's regulatory enforcement activities, Keith Hawkins' Law as Last Resort, identified the central role that carefully managed public perceptions play in facilitating HSE's regulatory work. Hawkins found that prosecution, as a form of enforcement activity, was a highly symbolic act that was calculated to express a particular message to a wider audience, and that enforcement activity is utilised as a way of advertising the goals, values, and strength of the agency. ${ }^{36}$ This maintenance of a positive social profile reaffirms the agency's mandate to regulate:

"Prosecution, when viewed as right, proper, and appropriate, is legitimate... and can therefore make both an expressive claim founded in moral legitimacy and an instrumental claim derived from action in the public interest. "37

As such, it follows that regulatory activity that is expressly rejected as not right, proper, or appropriate, can threaten this mandate. Bardach and Kagan demonstrated that the imposition

\footnotetext{
${ }^{33}$ These responsibilities are bound up within the general duty under Section 2(1) of the HSWA to 'ensure, so far as is reasonably practicable, the health, safety and welfare at work of all his employees'.

${ }^{34}$ A. Dodds, 'The Core Executive's Approach to Regulation: From 'Better Regulation' to 'Risk-Tolerant Deregulation" (2006) 40 Social Policy \& Administration 526; P. Hampton, Reducing Administrative Burdens: Effective Inspection and Enforcement (2005).

${ }^{35}$ Robens, op. cit., n. 32.

${ }^{36}$ Hawkins, op. cit., n. 1, p. 207, p. 306.

${ }^{37}$ id., p. 417.
} 
of external requirements, arbitrary or heavy-handed enforcement, and lack of incentive to participate, can cause regulators and their activities to appear illegitimate, and so undermine the stakeholder commitment required for successful future regulation. ${ }^{38}$ HSE's Enforcement Policy Statement emphasises the importance of proportionality, targeting, consistency, accountability, and transparency as principles that should guide the agency's enforcement activities. $^{39}$ It may be argued that frivolous cases which appear not to accord with these principles are capable of undermining HSE's otherwise broadly positive public trust profile, ${ }^{40}$ even though they do not always involve the agency.

\section{The Concept of 'Regulatory Myths'}

The regulatory response to the frivolous cases outlined above has characterised them as a form of 'regulatory myth' which straightforwardly misrepresent the objective 'truth' of health and safety regulation. The factual fuzziness and uncertain veracity of these cases means that the concept of myth or 'urban legend' provides an informative framework for their analysis. Urban legends are contemporary apocryphal stories that are told as true and widely believed, but which lack factual verification, and which possess a fluid, dynamic, 'subterranean' character that eludes simple analysis. ${ }^{41}$ They possess an abstract, general quality that allows them to pass swiftly into common discourse and spread outwards from their original source (if indeed there is a single, factual source). Brunvand has investigated and documented a plethora of urban legends, and suggests that (like other legends) they possess three key features; a strong basic story-appeal, a foundation in actual belief, and a meaningful message

\footnotetext{
${ }^{38}$ E. Bardach and R. Kagan, Going by the Book: The Problem of Regulatory Unreasonableness (1982).

${ }^{39}$ HSE, op. cit., n. 30.

${ }^{40}$ Walls et al., op. cit., n. 26.

${ }^{41}$ Goode and Ben-Yahuda, op. cit., n. 9, p. 108; J. Brunvand, The Vanishing Hitchhiker: American Urban Legends and Their Meanings (1981); J. Brunvand, Too Good to be True: The Colossal Book of Urban Legends (1999).
} 
or moral. ${ }^{42}$ This second feature is crucial; although the factual basis of the story may be questionable, urban legends are taken to be true, and are passed on as fact. Because of this, they acquire a social significance that sets them aside from other stories.

The distinctiveness of urban legends, according to Donovan, stems from their claims to be news and their relationship to realistic and contemporary social situations rather than fantastic or supernatural events. ${ }^{43}$ Urban legends are only largely false as the factual fuzziness that they involve does not mean that they cannot have some root in real events; as Best and Horiuchi observe, "whether a legend begins with a real incident or as a fictional tale, it is told and retold, often evolving as it spreads", ${ }^{44}$ and this process of reiteration reinforces the story's credibility. The contemporaneousness and realism of the urban legend also contributes to its appeal, rooting it in the here and now, and facilitating its primary purpose as a form of social commentary which expresses some 'truth' about the modern world. ${ }^{45}$ Like all forms of myth, these urban legends exist to reinforce some form of moral message (such as the prohibition or disapproval of conduct), or otherwise reflect an issue that prompts public anxieties. Urban legends in particular are characterised by the timeliness and topicality of these underlying concerns.

Urban legends theorists link the spread of the stories to public anxieties about changes in increasingly complex modern societies. According to Brunvand, urban legends usually "depict a clash between modern conditions and some aspect of a traditional life-style", 46 hence the prevalence of stories involving fast-food culture (such as those involving the

\footnotetext{
${ }^{42}$ Brunvand, id. (1981), p. 10.

${ }^{43}$ P. Donovan, 'Crime Legends in a New Medium: Fact, Fiction and Loss of Authority' (2002) 6 Theoretical Criminology 189, p. 190.

${ }^{44}$ J. Best and G. Horiuchi, 'The Razor Blade in the Apple: The Social Construction of Urban Legends' (1985) 32 Social Problems 488, p. 492.

${ }_{45}^{45}$ Brunvand, op. cit. (1981) n. 41, p. 11.

${ }^{46}$ id., p. 189.
} 
discovery of foreign objects in takeaway meals), the breakdown of traditional family structures (such as those involving negligent parenting or babysitters), and forms of 'stranger danger' or criminality (such as the numerous legends involving murderous hitchhikers or night-prowlers). Crime legends in particular express "a sense of chaos and an absence of socially sustained protection", ${ }^{47}$ reflecting social concerns over the prevalence of new crime risks and the ability of the state to control these risks. For example, Best and Horiuchi's account of 'Halloween sadist' stories identifies the social strains that underpin the emergence of newspaper reports about the distribution of adulterated treats to children, linking this (unfounded) legend to an increased social awareness of threats to children, an increasing crime rate and public fear of crime, and a breakdown of wider trust and social solidarity. ${ }^{48}$

A clear parallel can be drawn, when considering urban crime legends in particular, with theoretical accounts of the contemporary politics of law and order in late-modern society, in particular David Garland's analysis of a 'Culture of Control' ${ }^{49}$ For Garland, the erosion of the certainties of the modernist state in a period of late modernity have increased feelings of ontological insecurity, and led to a 'punitive turn' in public attitudes towards crime. The public has been required to adapt to high crime rates as a fact of life, as well as a perceived decline in the ability of the sovereign state to guarantee law and order. The result is that:

"A collectively raised consciousness of crime... has been written into our common sense and the routines of our everyday life. It is woven into the text of our news programmes... and, in more fantastic forms, into our urban myths... "50

Concerns over crime as a form of risk reflect wider social uncertainty, and lead to increased fear of crime, demands for tougher punishment and a more emotive approach to crime policy,

\footnotetext{
${ }^{47}$ Donovan, op. cit., n. 43, p. 190.

${ }^{48}$ Best and Horiuchi, op. cit., n. 44, p. 493.

${ }^{49}$ Garland, op. cit., n. 10.

${ }^{50}$ id., p. 163.
} 
the vilification of offenders as 'others', and a perpetual sense that the criminal justice system is in crisis. ${ }^{51}$ So just as urban myths reflect public concerns over emergent technological health risks posed by, for example, mobile phones, ${ }^{52}$ so they also reflect perceived emergent crime risks inherent in this late-modern society, including the risks of abduction of children from public places by strangers. ${ }^{53}$

So how does an understanding of the concept of 'urban crime legends' help us to interpret frivolous cases? To begin with, it appears that the 'hanging baskets' and 'conkers' cases, and others, conform to the basic premise in that they are told as true and widely believed, but lack factual verification. They possess what Donovan refers to as 'constructed non-clarity',54 whereby the uncertain veracity of the stories serves to actually increase their appeal by preventing clear scrutiny and allowing for the imputation of numerous variations which increase their appeal. The difficulty in debunking a story which is factually fuzzy and lacking in clarity means that refuting a story can enhance its perceived veracity; urban crime legends are constructed through a contested process of persuasion, where storytellers attempt to convince their audience of the story's veracity and 'face down' factual objections put in its way, despite the fact that they are, for the most part, false. ${ }^{55}$ This forces the story to adapt, ironing out inconsistent facts and 'generalising' the story onto a less disprovable footing. ${ }^{56}$ This interpretive flexibility explains the ease with which these frivolous cases have passed into common knowledge. They appear to fulfil Brunvand's key criteria for myths as they

\footnotetext{
51 id., p. 6-20.

52 A. Burgess, 'Mobile Phones and Service Stations: Rumour, Risk and Precaution' (2007) 54 Diogenes 125.

${ }^{53}$ It may be argued that the high levels of public interest in, and media coverage of, the Madeleine McCann abduction case of 2007 reflects this type of emergent consciousness of a specific crime risk (though this incident does not, of course, constitute an urban myth). Myths relating to child abduction in themselves are not new, however; Brunvand documents a long tradition of child-abduction myths: op. cit. (1981), n. 41, p. 182. Parallels can be drawn with the widespread concern over the supposed 'white slave trade' which prompted the introduction of the Mann Act in the USA in 1910: Donovan, op. cit., n. 43, p. 202.

${ }^{54}$ Donovan, id., p. 207.

${ }^{55}$ Williams, op. cit., n. 11, p. 349.

${ }^{56}$ P. Donovan, 'How Idle is Idle Talk? One Hundred Years of Rumor Research', (2007) 54 Diogenes 59, 69; J. Kapferer, Rumors: Uses, Interpretations, and Images (1990), p. 244.
} 
possess a strong basic story-appeal (rooted in the vivid events portrayed), have a foundation in actual belief, and contain some form of moral message.

By conceptualising 'frivolous cases' as a form of urban crime legend, we can understand the enduring popularity that they possess. The strong story-appeal of urban legends are (unlike jokes) rooted in something more substantial than an amusing set of events; they endure because they prompt a specific response in the audience. Heath et al. categorise urban legends as forms of 'emotional meme', cultural analogues of biological genes, which compete to be selected and propagated in the social environment. ${ }^{57}$ Only the strongest ideas will survive and multiply in this cultural competition for the 'survival of the fittest'. As well as performing an 'informational' function, communicating a moral or practical message to the audience, successful urban legends also have an emotional basis, in that they provoke shared emotional reactions among tellers and audiences. Anger, anxiety, fear, and disgust can all be induced by exposure to urban legends. Crucially, these emotional responses are shared among those privy to the story; urban legends are passed on because the shared emotion enhances interaction and promotes social solidarity. ${ }^{58}$ There is a parallel between urban legends and public discourses about the 'compensation culture' in relation to the emotional content of the stories involved; Haltom and McCann conceptualise tort tales as provoking a shared emotional condemnation of the 'greedy' and 'undeserving' complainant as lacking in 'moral discipline'. ${ }^{59}$ In these cases, the social solidarity produced is a deliberate outcome of the instrumental objective of the story; they exist to create and promulgate a politically-

\footnotetext{
${ }^{57}$ C. Heath, C. Bell and E. Sternberg, 'Emotional Selection in Memes: The Case of Urban Legends' (2001) 81 Journal of Personality and Social Psychology 1028.

58 id., p. 1030.

${ }^{59}$ Haltom and McCann, op. cit., n. 22, p. 24.
} 
motivated consensus in favour of tort reform, and to restate social concerns about an increasingly individualistic society. ${ }^{60}$

The endurance of urban crime legends and regulatory myths, and their ready acceptance into wider public discourse is, therefore, linked to their communicative power, not only as reflections of existing fears, but also as shared social experiences. They do not simply reflect what we already believed about crime and disorder; they also lead us to participate in shared emotional 'events', registering and experiencing our anger, disgust or other emotion in conjunction with others. This can provoke specific responses such as resentment or hostility towards a particular social group or organisations, ${ }^{61}$ altered tolerances and perceptions of risk, ${ }^{62}$ and social bonding with others who experience the same emotional response. ${ }^{63}$ Successful urban crime legends and regulatory myths are those that provide this emotional content as well as a functional message; the capacity to underlay the substantive story with a visceral response-trigger makes legends of this sort highly effective communicative events.

\section{The Meanings of Regulatory Myths}

The key to understanding the importance of urban crime legends and regulatory myths as social phenomena lies in identification of the moral or functional meanings that they possess, and which prompt the communicative and emotive responses outlined above. Why do stories about regulatory enforcement emerge and what messages do they contain that make them such popular and enduring social memes? Crucially, how do the moral meanings of these stories relate to their function as emotional events? As Donovan observes, rumours and urban

\footnotetext{
${ }^{60}$ Morris, op. cit., n. 21, p. 366.

${ }^{61}$ Heath et al., op. cit., n. 57, p. 1031.

${ }^{62}$ P. Slovic, 'Perceived Risk, Trust, and Democracy' (1993) 13 Risk Analysis 675; M. Sinaceur, C. Heath, and C. Cole, 'Emotional and Deliberative Reactions to a Public Crisis: Mad Cow Disease in France' (2005) 16 Psychological Science 247.

${ }^{63}$ Donovan, op. cit., n. 56.
} 
legends constitute " a genre that fills a specific informational niche-dynamic and historically variable". ${ }^{64}$ Urban legends represent the crystallisation of a set of generalised anxieties into one specific story, so as to enable individuals to make sense of their concerns and respond, for instance, by avoiding certain situations or places, being more vigilant and wary of strangers, and so on. How do these understandings of the functional meaning of urban legends relate to the example of regulatory myths?

The most prominent concerns contained within regulatory myths are very similar to those Brunvand identified as underpinning urban legends generally; a "clash between modern conditions and some aspect of a traditional life-style"65 and a sense of threat posed to traditional society by the late-modern social world. Many theoretical accounts of modern society have identified the sociological importance of public concerns over the risks to health and wellbeing that changes in society and the erosion of traditional certainties are perceived to pose. ${ }^{66}$ Briefly, it is argued that major changes in late- $20^{\text {th }}$ century society, such as increased globalisation and population mobility, the increasingly flexible economy and employment market, the pluralisation of culture and the media, and the breakdown of traditional structures of family, community and sovereign state, have created an increasingly fluid, changeable and uncertain society which, although freer, also appears to be more unpredictable and bounded by risk than ever before. New technology and scientific developments create "new parameters of risk and danger as well as offering beneficent possibilities for humankind" ${ }^{67}$

\footnotetext{
${ }^{64}$ id., p. 68 (original emphasis).

${ }^{65}$ Brunvand, op. cit. (1981), n. 41, p. 189.

${ }^{66}$ Z. Bauman, Liquid Modernity, (2000); U. Beck, Risk Society: Towards a New Modernity, (1992); F. Furedi, Culture of Fear: Risk-Taking and the Morality of Low Expectation, (1997); Garland, op. cit., n. 10; A. Giddens, Modernity and Self Identity: Self and Society in the Late Modern Age, (1991).

${ }^{67}$ Giddens, id., p.28.
} 
In particular, the erosion of past certainties have increased public feelings of ontological insecurity, and led to risk intolerance. The breakdown of social structures and the resultant sense of uncertainty is related to a corresponding decline in 'traditional values', manifested via the questioning of accepted wisdom and the pluralisation of moral discourse, leading to a social world in which ideas of what is acceptable or desirable are contested and ambiguous. As Furedi observes, "When even the more fundamental questions are far from clear-cut, basic decisions about life appear increasingly risky". ${ }^{68}$ This sense of uncertainty and insecurity prompts appeals from politicians, media commentators, and the public, for a return to traditional values and the reassertion of the shared commonalities that underpin existing social conventions. ${ }^{69}$ Traditional practices and morality are valued as a way of establishing some form of fixity and order in a relentlessly progressive and changeable world.

These concerns over the erosion of a more certain, more 'traditional', way of life are evidenced through regulatory myths. The narrative features of the stories discussed all centre on regulatory challenges to explicitly traditional activities; the game of conkers, pancake races at the Cathedral, and municipal floral displays in market towns. The regulatory myth stories all discuss the undesirability of imposing 'regulatory' control over established, time-honoured practices which have previously existed for many years without any legal supervision. A recent newspaper article referenced eight regulatory 'frivolous cases', all of which involved 'traditional' activities and events; the 'conkers' story was included, along with the banning of traditional woodcraft bridges on Dartmoor as 'unsafe', the banning of 'lucky' sixpences in Christmas puddings as choking hazards, and the cutting down of trees to prevent children climbing them. ${ }^{70}$ Similar to tort tales about the compensation culture (which they also

\footnotetext{
${ }^{68}$ Furedi, op. cit., n. 66, p. 148.

${ }^{69}$ id., p. 149; also, Giddens, op. cit., n. 66, p. 206.

${ }^{70}$ The Times (05 May 2008, p9). The other cases referenced were: the banning of mistletoe as a workplace

Christmas decoration due to concerns over the potential for sexual harassment; the removal of a 100-year-old
} 
reference regularly), these stories imbue the pre-legal society invoked with an idealised moral character centred on values of self-reliance as opposed to the legal management of individuals' lives. ${ }^{71}$ The implication is clear; the extension of legal regulation constitutes a palpable and unwelcome threat to traditional ways of life.

It is noticeable that the version of traditional society referenced is a rather idealised one, centring on wholesome outdoor pursuits, religious observance, and the vision of a parochial and middle-class rural England invoked by former Prime Minister John Major in his infamous 1993 speech about the impact of European harmonisation on the British way of life:

"Fifty years on from now, Britain will still be the country of long shadows on cricket grounds, warm beer, invincible green suburbs...and, as George Orwell said, 'Old maids bicycling to holy communion through the morning mist ${ }^{\prime} . . ., 72$

The invocation of traditional values and ways of life in this form indicates the deep-seated anxieties that underpin the resistance to their control. Giddens described tradition as a mechanism which "creates a sense of the firmness of things that typically mixes cognitive and moral elements", ${ }^{73}$ and identifies the desire for the reconstruction of traditions as reflective of a wish to "return to sources of moral fixity in day-to-day life, in contrast to the 'always revisable' outlook of modern progressivism". ${ }^{74}$ The hostile media reports outlining regulatory 'attacks' upon traditional activities reflect an unease at the erosion of moral fixity and the resultant insecurity of late-modern life; regulatory myths explicitly relate to wider anxieties and are, as a result, socially significant.

\footnotetext{
swing from an oak tree on a village green; ramblers having to complete risk assessments before hill-walking; and a cross-channel swimmer being prevented from training without safety supervision.

${ }^{71}$ Haltom and McCann, op. cit., n. 22, p. 305.

${ }^{72}$ Speech to the Conservative Group for Europe, 22 April 1993.

${ }^{73}$ Giddens, op. cit., n. 66, p. 48.

${ }^{74}$ id., p. 207.
} 
While recognising the status of regulatory myths as reflective of wider concerns is useful, it must be noted that they differ significantly from late-modern crime anxieties in general; the message of these stories is defiantly anti-regulation and legal control, and reflects a reduction in public confidence in law enforcement bodies. Public attitudes towards crime in latemodernity typically centre on an increased fear of crime and demands for greater use of state power to protect the public, ${ }^{75}$ and this, when coupled with a wider public risk-aversion and moral objection to risk-creators, results in support for increased legal control. ${ }^{76}$ Indeed, regulatory myth stories are paradoxical in that they run contrary to the general trend for public demands for greater regulation where legal controls are perceived to have failed, such as in the aftermath of a major disaster. ${ }^{77}$ Most urban crime legends involve a troubling social risk, and promote formal or informal systems of control. The desire for security identified in accounts of the 'risk society' seems logically to constitute fertile ground for risk regulation regimes, yet in many cases the opposite has proved to be true. It may be that "public protection has become the dominant theme of penal policy", ${ }^{78}$ but this does not translate into acceptance of the regulatory state nor, in a broader context, of systems of civil liability for risk creation. Like tort tales, they embody an inherent distrust of the law, which is viewed as the primary source of the problem in question. So why does this hostility towards the law arise, contrary to the regulator-friendly outcomes that might be expected?

First, it must be noted that this tension exists within the literature discussing the contemporary politics of law and order. The emergence of punitive public attitudes towards crime, and the trends towards toughened penal policies and harsher sanctions that feature in this 'culture of

\footnotetext{
${ }^{75}$ Garland, op. cit., n. 10, p. 10-14.

${ }^{76}$ Although this is tempered by scepticism about the efficacy of that system: J. Roberts and M. Hough, Understanding Public Attitudes to Criminal Justice, (2005) 32.

${ }^{77}$ Almond, op. cit., n. 2; C. Parker, 'The 'Compliance Trap': The Moral Message in Responsive Regulatory

Enforcement', (2006) 40 Law \& Society Review 591.

${ }^{78}$ Garland, op. cit., n. 10, p. 12.
} 
control' are accompanied by a concomitant breakdown in trust in government, and recognition of the limited competence of the sovereign state. Garland identifies these changes as underpinned by a 'crisis of penal modernism', a widespread recognition that 'the 'modern' arrangements for crime control - organized through the specialist agencies of the criminal justice state - may no longer be adequate to the problem of crime". ${ }^{79}$ This sense of crisis, an outcome of an increased sense of institutional and societal uncertainty and disillusionment during the 1970s, led to the abandonment of established 'correctionalist' criminal justice practices. ${ }^{80}$ As efforts to rehabilitate offenders within the criminal justice system were discredited, so the institutions which pursued these goals found their competence called into question. The sovereign state is seen as no longer having the ability to affect positive outcomes, and the outcomes it pursues are no longer accepted as valid.

The system of health and safety regulation utilised by HSE can be categorised as falling within this 'penal-welfarist' model, in that it primarily centred on consensual complianceseeking activities. ${ }^{81}$ Garland's characterisation of penal-welfarism emphasises that this model "shared in the progressive statist politics of the welfare state. It assumed without question the possibility and desirability of reintegrating delinquents and deviant individuals. And it looked to...professional treatment and public provision, to bring this about". 82 These correctionalist and welfarist assumptions also underpin the Robens model; the Health and Safety Commission (the body responsible for health and safety policymaking from 19742008) was categorised as the "most corporatist body in Britain". 83 As such, the late-modern climate may have called into question the foundations of political support for this regulatory

\footnotetext{
79 id., p. 20.

${ }^{80}$ See, for example, R. Martinson, 'What Works? - Questions and Answers About Prison Reform', (1974) 35 The Public Interest 22.

${ }^{81}$ Hawkins, op. cit., n. 1; Hutter, op. cit., n. 32; Robens, op. cit., n.32.

${ }^{82}$ Garland, op. cit., n. 10, p. 44.

${ }^{83}$ Hutter, op. cit., n. 32, p. 24.
} 
project, as evidenced by David Cameron's 2008 speech to the Conservative Party Conference, in which he explicitly referenced regulatory myth cases when criticising health and safety regulation. ${ }^{84}$

Secondly, this malaise affecting accepted understandings of criminal justice issues is related to a change in the way that law enforcers are perceived by the wider public. Garland argues that the crisis of penal modernism reflected the 'declining influence of social expertise' within the newly liberalised society of the late $20^{\text {th }}$ century. ${ }^{85}$ As a climate of free-market and individualistic politics has taken hold, accompanied by a culture of managerialism, the perceived credibility of 'experts' has declined, undermined by the new emphasis on selfreliance. This scepticism has affected the social standing of politicians, civil servants, and medical and social work professionals, as well as scientists, risk experts, and criminal justice professionals. ${ }^{86}$ A decline in social deference and increased mistrust of authority has reduced the perceived status of official knowledge, a trend which has clear implications for regulators such as HSE. This point helps explain some of the reasons why regulatory myth cases emerge in the first place; like tort tales, they are propelled by instrumental and institutional concerns over the encroachment of the law into fields of free-market individualism, specifically business interests and the functioning of the economy.

Thirdly, public hostilities towards regulatory law are not a particularly new phenomenon and reflect the long-standing ambiguity of status associated with systems of legal control over

\footnotetext{
84 "This attitude, this whole health and safety, human rights act culture, has infected every part of our life. If you're a police officer you now cannot pursue an armed criminal without first filling out a risk assessment form. Teachers can't put a plaster on a child's grazed knee...it's not a bigger state we need: it's better, more efficient government." The Guardian, (http://www.guardian.co.uk/politics/2008/oct/01/davidcameron.toryconference1) $01 / 10 / 2008$

${ }^{85}$ Garland, op. cit., n. 10, p. 150.

${ }^{86}$ id., p. 151; Furedi, op. cit., n. 66, p. 130; Slovic, op. cit., n. 62.
} 
corporate conduct, ${ }^{87}$ which is linked to the mala in se/mala prohibita distinction between 'mainstream' criminal and regulatory offences. Regulation typically involves the management of lawful conduct rather than the prohibition of inherently harmful conduct, and so it is regarded differently to the criminal law, prompts less 'punitive' public attitudes, and is viewed as less unambiguously in the public interest because it involves balancing competing interests which are linked to wider ideological debates over the roles of capital and the state. ${ }^{88}$ Livingstone and Lunt found that public attitudes towards regulation are ambivalent, in that recognition of the protective public goods associated with regulatory control is offset by a deep-seated resentment of the law's restrictions on the free market. ${ }^{89}$ And it is this interest in defending the status of the free-market that provides the key to understanding why regulatory myth stories of this sort emerge, in addition to the explanations of their meaning and content provided above. Regulatory myth cases emerge and gain popular currency because they fit so comfortably into an existing political discourse that seeks to delegitimate the regulatory state and validate its restriction, and they are selectively reported on this basis.

The thematic features of regulatory myths outlined here all contribute to the creation of a motif of regulatory unreasonableness and an antagonistic representation of health and safety regulators, and it is argued here that this is part of a political commentary that goes far beyond the 'joke' content of such tales. These myth stories communicate the idea that the basis on which authoritative statements about the expertise of health and safety regulators and the need for regulatory controls are made is open to dispute, and this is reflected in the 'postauthoritative' content of the stories $;{ }^{90}$ just as the myths themselves are almost impossible to

\footnotetext{
${ }^{87}$ S. Livingstone and P. Lunt, 'The Politics of Consumption/The Consumption of Politics: Representing Citizens and Consumers in Media and Communications Regulation', (2007) 611 The Annals of The American Academy of Political and Social Science 51; Wells, op. cit., n. 5.

${ }^{88}$ Almond, op. cit., n. 6; Hawkins, op. cit., n. 1, p. 117-119.

${ }^{89}$ Livingstone and Lunt, op. cit., n. 87, p. 61.

${ }^{90}$ Donovan, op. cit., n. 56, p. 66-7.
} 
disprove, so the efforts of regulators to assert some form of truth is depicted as representing "the folly and hubris of those who continue to trust in their own information-sorting abilities". ${ }^{91}$ Regulatory myth stories critique the attempts of regulatory 'experts' to juridify and control risk, and it is the encroachment of law that gives rise to anxiety, not its absence. This is the same dynamic that underpins the emergence of stories about the emergent 'compensation culture' in the United States, United Kingdom and elsewhere, another example of the 'unwelcome' juridification of human interactions. Within the 'tort tales' that abound in this sphere, ${ }^{92}$ concerns over perceived increases in the volume of personal injury litigation and its effects on insurance premiums, the economy, and future risk-averse behaviour have been made manifest, particularly as a result of the sensationalist media coverage these stories receive. ${ }^{93}$

Like regulatory myth cases, arguments about the onset of a compensation culture emerge in response to two core pressures; political opposition to the role that regulatory systems of law play in fettering free-market business interests, and deep-seated ideological concerns about the impact of the law upon traditional values and individual autonomy. As Haltom and McCann observe, the hostile attitudes found within public narratives about regulation tap into "enduring ideological commitments endorsing individual responsibility and disparaging legalistic state paternalism". ${ }^{94}$ The first of these two points reflects the instrumental function that tort tales have as part of a wider political campaign on a specific issue; the use of tort tales to bolster efforts to shape the public agenda on the issue of reform of the civil compensation system. 'Tort tales' constitute a form of 'legal lore' which feeds directly into the lawmaking process by influencing the ways in which political actors frame and discuss the

\footnotetext{
${ }^{91}$ Donovan, op. cit., n. 43, p. 207.

${ }^{92}$ Such as the 'McDonald's Hot Coffee Case': Haltom and McCann, op. cit., n. 22.

${ }^{93}$ Morris, op. cit., n. 21, p. 364; Williams, op. cit., n.11, p. 349.

${ }^{94}$ Haltom and McCann, op. cit., n. 22, p. 24.
} 
issues in question; such tales are readily invoked and used to support calls for the restriction of individual recourse to the law. Regulatory myth cases are utilised in a similar way by politicians seeking to influence specific policymaking processes, relating to both reform of civil compensation systems and the diminution of State-based systems of regulatory control. ${ }^{95}$

The second point reflects a more generalised set of cultural meanings that tort tales and regulatory myths reflect. For Haltom and McCann, 'tort myths' tie into ideological concerns about the erosion of traditional American norms of self-reliance and individual responsibility, and it is conservative political proponents of these values who drive the media backlash against this opponent: "Frivolous litigants displacing responsibility for self-inflicted harm and greedy lawyers abusing the legal system have joined the growing catalog of Others...stigmatized by neoconservatives and neoliberal proponents as undeserving and dangerous". ${ }^{96}$ Like tort tales, regulatory myths speak to the issue of individual responsibility, depicting the encroachment of the law into individual choices via the banning of valued activities, and the restriction of individual autonomy through regulatory control. This is a broader issue than the instrumental effect on a specific policy issue, in that it encompasses the overall relationship between the individual and the state; the deregulatory message is a general one, and reflects a concern over the emergence of an increasingly individualistic society. But while Haltom and McCann's tort tales focus on attacking the 'users' of law as those who are morally responsible for this individualisation, regulatory myths primarily attack the system of law itself, rather than those 'feckless' or 'greedy' enough to invoke it.

The role played by the media in reporting regulatory myth cases is fundamental in understanding how and why these stories become as influential and significant as they do. As

\footnotetext{
${ }^{95}$ op. cit., n. 84; Haltom and McCann, op. cit., n. 22, p. 277; Williams, op. cit., n.11, p. 350.

${ }^{96}$ Haltom and McCann, id., p. 71.
} 
well as picking up and reporting regulatory myth cases on the basis of their entertainment value, and then disseminating established myths as 'news', the mass media also supplies "selective stories about 'real life' that provide a narrative foundation and affirmative evidence for the dominant lore". ${ }^{97}$ The media focus upon stories that individualise the issues and reduces them to the level of a direct dispute between two adversarial actors, about whom moralistic judgements about character and responsibility can be made in line with prevailing sentiments and ideological schema of understanding. So the regulatory myths discussed in this paper (the 'conkers', 'hanging baskets', and 'pancake race' stories are good examples) present a direct conflict between the overbearing and interfering regulator and the values of tradition and individual freedom as embodied in the everyman 'victim', and leave little room for ambiguity or complexity in assessment of the two. The simplification of the story in order to fit the demands of routine news production also results in the extreme and un-nuanced public responses that are produced as a result; the reductionist nature of the stories is what gives the stories their communicative power.

\section{Regulatory Myths as Legitimacy Challenges}

Regulatory enforcement practices form part of a wider communicative discourse about the nature and purpose of regulatory law, the boundaries of acceptable conduct, and the status and legitimacy of the law and regulators. The vast majority of regulatory activities undertaken by HSE are conciliatory and negotiated in character, ${ }^{98}$ and this remains the case despite the introduction of increased penalties under the Health and Safety (Offences) Act 2008 because resort to formal criminal sanctioning occurs relatively infrequently and as a last resort. While there is some evidence that HSE may be shifting towards a more punitive regulatory approach characterised by tougher penalties and an increased willingness to prosecute in serious

\footnotetext{
97 id., p. 273.

98 op. cit., n. 81 .
} 
cases,${ }^{99}$ this post-Hampton regulatory paradigm also emphasises the importance of reducing the burdens of regulation upon business. ${ }^{100}$ This dictates an increasing shift away from regulatory inspection and enforcement, and towards the issuing of advice and guidance as part of the cooperative 'corollary of interest' that the Robens Report envisaged. ${ }^{101}$ Securing the consent of those subject to regulatory control is important in many more cases than confrontational enforcement measures are used, and this consent is contingent upon the public profile of the agency in the eyes of its regulatory audiences.

One of the most important messages that enforcement action communicates concerns the organisational legitimacy of the regulatory agency. Legitimacy refers to the foundation of public validation which underpins the actions of state institutions; it is contingent upon the belief in the legitimacy of a social order possessed by those subject to it. Belief in the legitimacy of a regulatory agency is predicated upon the perceived legal validity (procedural correctness) and moral justifiability (in accordance with shared values) of the agency's conduct and its resultant outcomes. ${ }^{102}$ The regulated stakeholder population, the general public, and government actors, are all prompted to evaluate the legitimacy of a regulatory agency. While positive regulatory outcomes can be valuable in constructing agency legitimacy, there is a commensurate impact associated with negative regulatory outcomes, which can undermine agency legitimacy. As Parker observes, regulatory enforcement agencies that "do not receive external political support... will be left without 'license' to regulate effectively". ${ }^{103}$ In particular, failure to secure preferred outcomes in cases of public

\footnotetext{
${ }^{99}$ P. Almond, 'An Inspector's-Eye View: The Prospective Enforcement of Work-Related Fatality Cases', (2006) 46 British Journal of Criminology 893; R. Baldwin, 'The New Punitive Regulation', (2004) 67 Modern Law Review 351; see also the recent House of Lords decision in $R$ v. Chargot \& Ors. [2009] 1 WLR 1, which restated a judicial interpretation of health and safety enforcement as a matter of considerable importance.

100 op. cit., n. 34.

${ }^{101}$ Robens, op. cit., n. 32, para. 41.

${ }^{102}$ Almond, op. cit., n. 2; Beetham, op. cit., n. 4.

${ }^{103}$ Parker, op. cit., n. 77, p. 615.
} 
concern can undermine the legitimacy requirement of moral justifiability (or 'rule-content') because the agency appears not to be acting in accordance with social values. If HSE is no longer seen as acting in the public interest by fulfilling its protective functions, its legitimacy can be damaged, compromising its ability to regulate effectively in the future.

The relationship between conceptualisations of 'myth' and the notion of legitimacy is particularly important in the regulatory sphere. In many ways, the use of myth by regulators is important because it can function so effectively as a communicative tool. For example, Hawkins has documented the methods by which enforcement action (in the broader sense, including informal techniques) is used to preserve the symbolic status of environmental pollution regulators, and health and safety regulators. In particular, he identifies the way in which regulators target enforcement action in such a way as to construct a 'myth' about their agency by, for instance, prosecuting only where there is a very low risk of failure in order to create an impression of infallibility. ${ }^{104}$ In his study of water authority inspectors, Hawkins found evidence of regulators 'bluffing' in order to influence corporate responses to an incident, exaggerating the likelihood of prosecution, overstating the range of potential sanctions, and exploiting the information deficit of regulated companies to ensure that they adhered to standards higher than those actually incumbent upon them. ${ }^{105}$ The symbolism of regulatory myths provides a means of expressing the regulator's values on the public stage.

These communication techniques have assisted in shaping HSE's broadly positive public trust profile. As Haines and Gurney observe, regulators legitimate their own existence "by affirming the importance of the regulatory goal that it [the agency] is directed at achieving

\footnotetext{
${ }^{104}$ Hawkins, op. cit., n. 1, p. 382.

105 K. Hawkins, Environment and Enforcement: Regulation and the Social Definition of Pollution (1984) 149155.
} 
and by demonstrating how effective it is in achieving that goal". ${ }^{106}$ Walls et al. discovered that HSE was broadly regarded as acting in the public interest, but that public disquiet over the state of the railway system transferred into negative assessments of the Railway Inspectorate, at the time a sub-section of HSE. ${ }^{107}$ This suggests that a sense of positive or negative affect, grounded in wider perceptions of the field in which the regulator works, can be highly influential in shaping agency evaluation. Yet there is evidence that these attitudes are based upon a rather patchy and incomplete public understanding of the agency's role, meaning that public perceptions are fragile and changeable. Walls et al. did find that evaluations of HSE were negatively affected by the perceived issue of petty regulation and what were viewed as the 'funny little regulations' that the agency implemented, ${ }^{108}$ suggesting that regulatory myths do affect public judgements. These stories have significant communicative power, and so can enter public awareness at the general level, shaping subsequent evaluations on more specific issues.

Regulatory myths have a negative impact on the perceived legitimacy of regulatory agencies and systems of law. By portraying the imposition of prohibitive regulatory control over traditional and valued activities, and the focus of regulators on petty issues rather than serious health and safety risks, the moral justifiability of the regulator's actions are called into question; it does not appear to be acting in accordance with the shared values of society. David Cameron's speech provides an example of this divergence between this version of regulation and 'common-sense' public values. ${ }^{109}$ More seriously, regulatory myth cases also involve an explicitly political attack on the procedural validity of the regulator and the law; the appearance of capriciousness and 'regulatory unreasonableness' calls into question the

\footnotetext{
${ }^{106}$ Haines and Gurney, op. cit., n. 2, p. 372.

107 Walls et al., op. cit., n. 26, p. 146.

108 id., p. 141-3.

109 op. cit., n. 84.
} 
right of the regulator to regulate, rather than just how this is done. As such, regulatory myths deserve attention as serious substantive challenges to health and safety law.

\section{Conclusions}

This account of the social phenomenon of 'regulatory myth' cases has demonstrated that negative portrayals of health and safety law, and of regulators such as HSE, have a social currency that makes them both important and significant. Myth-type cases such as the 'hanging baskets' and 'conkers' stories are widely recognised and accepted as shorthand representations of health and safety regulation, and reflect generalised public anxieties, adding to their success as 'social memes'. The status of these stories as forms of 'urban legend' serves to increase their communicative power and heighten their popular appeal. The key recurrent theme within these stories, of a clash between the ineffective and capricious regulator on the one hand, and wider social interests on the other, constitutes an expression of public concerns over the breakdown of traditional social values and the perceived decline of social expertise and authority within late-modern society.

The link to these underlying concerns accounts for the widespread success of regulatory myth stories, and also forms the background to understanding their social significance. They are a form of challenge to the legitimacy of regulators and systems of legal control. By being seen to be acting in procedurally invalid and morally unjustifiable ways, public reserves of goodwill towards, and acceptance of, health and safety regulation are eroded. And this concern with public perceptions is more than a public relations exercise - good regulatory governance in the future depends upon the maintenance of a basis of consent. While an individual story about a pancake race is unlikely to do much lasting damage to HSE, the cumulative effect of many such stories is more significant. Walls et al. suggested that HSE's 
relative 'invisibility' in the public eye had saved it from detrimental association with negative case outcomes, but this invisibility is changeable in response to media coverage. ${ }^{110}$

Crucially, the argument put forward here has significant implications for the way that HSE and other bodies respond to these stories. There is a real danger that the 'constructed nonclarity' of these stories means that efforts to refute them via HSE's 'Sensible Risk Management' policy may instead enhance their transfer into the public consciousness. Engaging with the story can enhance its shelf-life and increase opportunities for reassertion of the original message; reconceptualising these stories as regulatory myths demonstrates that they are not necessarily responsive to reasoned debate. As discussed, positive affect plays a vitally important role in relation to agency profile; it may be more effective to 'tip the scales' of critical trust in HSE by reasserting the positive role of the agency as a protector of public interests than by countering negative stories, however egregious they may be. Shifting the context of the debate on health and safety entirely away from these stories perhaps provides a better way of recasting the nature of public discourse in this area. Regulatory myths appeal to a broad audience because of their irreverent content, but, as has been shown, they are silly stories that have serious implications.

${ }^{110}$ Walls et al., op. cit., n. 26. 